\title{
PRE-OPERATIVE NUTRITIONAL EVALUATION IN LIVER TRANSPLANT CANDIDATES
}

\author{
Avaliação Nutricional Pré-operatória de Candidatos a Transplante Hepático' \\ Daniela Salate Biagioni', Camila César Winckler², Regina Célia Callile de Paula ${ }^{3}$, \\ Milene Regina Bailo Gomes 4 , Ricardo Augusto Monteiro de Barros Almeida ${ }^{5}$, Juan Carlos Llanos ${ }^{6}$, \\ Giovanni Faria Silva ${ }^{7}$ Alexandre Bakonyi Neto ${ }^{8}$
}

\begin{abstract}
Objective: The high prevalence of malnutrition in patients with end-stage of liver disease requires broad intensive measures to evaluate the pre-operative nutritional status while on the waiting list, aiming early disturbance corrections and a better after-transplant prognosis. Methods: An assessment on 33 out of 44 prognosis on liver transplantation waiting list was performed from March, 2004 to January, 2005. The current body weight, dry body weight, ideal body weight, body mass index, the percentage of adequacy of dry body weight / ideal body weight, tricipital skin fold, mid-arm muscular circumference, uncorrected mid-arm muscular area, blood albumin levels, and total lymphocyte count were assessed. Results: Upon the use of the body mass index and percentage of adequacy of the dry body weight / body mass index assessments, higher frequency of eutrofic and obese patients were observed, respectively. The protein depletion was higher than fat depletion in those patients, probably related to the catabolism associated to the liver disease and physical inactivity. Conclusion: Many nutritional measures are necessary in order to improve the accuracy of the results.
\end{abstract}

Keywords: Nutritional Assessment, Liver Transplantation, Malnutrition, Total Lymphocyte Count.

\footnotetext{
Academic Degree:

1. Dietitians, Gastroenterology Specialist.

2. Transplantation Nurse Coordinator.

3. Psychologist.

4. Social Worker

5. Infectologist and Master in Tropical Diseases.

6. Assistant Surgeon in Gastroenterologic Surgery.

7. Assistant Professor in Gastroenterology /Hepatology.

8. Assistant Professor of Surgery.
}

Institution:

Division of Liver and Pancreas Transplantation, Department of Surgery, Botucatu Schoo of Medicine-UNESP, São Paulo, Brazil.

Mailing address:

Daniela Salate Biagioni

Rua Prefeito Tonico de Barros, 11 - Centro

CEP 18600-110 - Botucatu - SP - Brazil

Phone: 5514 3815-2960

E-mail : danisb@btu.flash.tv.br.

Recebido em: 12/07/2005

Aceito em: 01/11/2005

\section{INTRODUCTION}

Liver is the largest metabolic organ in the human body which integrates a wide range of complex biochemical processes: carbohydrate, fat and protein metabolism, vitamin storage and activation, detoxification and excretion of endogenous and exogenous products. ${ }^{1,2}$ Upon a liver failure, the development of protein energy malnutrition (PEM) can be observed.

The presence of PEM has been associated to adverse outcomes, such as lower graft and patient survival after liver transplant, ${ }^{3}$ high morbidity and mortality before ${ }^{1}$ and after liver transplant (LT), ${ }^{2}$ longer stay in the hospital and in the intensive care unit, more extensive procedures, ${ }^{4}$ as well as a decrease in the quality of life with deleterious effects on the immunological function. ${ }^{4}$

A careful nutritional assessment in LT candidates is mandatory, but no gold standard measures exist in order to assess the grade of malnutrition among such population. The aim of this study was to assess the nutritional status of candidates on the LT in a teaching hospital.

\section{METHODS}

Thirty-three out of 44 patients on the waiting list in the Liver Transplantation Division of the Botucatu School of Medicine UNESP were assessed from March, 2004 to January, 2005.

Such nutritional assessment was analyzed using anthropometric and biochemical parameters: current body weight (CBW), height, adequacy of tricipital skin fold (\%TSF), arm circumference (\% $\mathrm{AC})$, the blood albumin levels, and total lymphocyte counting 
(TLC). The dry body weight (DBW),${ }^{5}$ body mass index (BMI), ideal body weight (IBW),${ }^{6}$ the percentage on adequacy of the dry body weight / ideal body weight (\%DBW/IBW), the adequacy of mid-arm muscular circumference (\%MMC) and uncorrected midarm muscular area (\%MMA) were calculated.

\section{RESULTS}

The population was predominantly male $(87,9 \%)$ with mean age of $51 \pm 9,1$ years, inactive $(66,6 \%)$ and Child - Turcotte - Pugh (CTP) $\mathrm{B}$, or $\mathrm{C}(84,8 \%)$. The alcoholic cirrhosis was a present etiology in $42,4 \%$ patients, and associated to other etiologies in $63,7 \%$.

The patients were considered eutrophic and obeses whenever the IBM were $18,5-24,9 \mathrm{Kg} / \mathrm{m}^{2}$ and $\geq 30 \mathrm{Kg} / \mathrm{m}^{2}$, respectively. Other parameters were assessed by the percentage of adequacy, and patients with $<90 \%$ percentage of adequacy and $>90 \%$ eutrofic were considered undernourished. By using the adequacy of the tricipital skinfold, patients were classified obeses with a percentage of adequacy $\geq 120 \%$. By counting the albumin and total lymphocyte parameters, patients were classified depleted whenever the values attained $<3,5 \mathrm{mg} / \mathrm{dl}$ and $<2000 / \mathrm{mm}^{3}$, respectively.

By using the BMI and \%DBW/IBW assessment, the higher frequency of eutrofic $(42,4 \%)$ and obese (48,5\%) patients were observed, respectively. The protein depletion assessed by the $\% \mathrm{MMC}(60,6 \%)$ and $\% \mathrm{MMA}$ $(66,7 \%)$ was higher than the fat depletion assessed by the $\% \mathrm{TSF}(45,5 \%)$ in those patients. Thirty patients $(90.9 \%)$ exhibited albumin depletion, and 28 patients $(84,8 \%)$ showed lower TLC value. (Table 1$)$

\section{DISCUSSION}

Although the dry body weight has been calculated, the measurement dependants of the weight may mask the nutritional status because of the fluid retention. ${ }^{4}$ The fact the protein depletion was higher than the fat depletion is probably related to the catabolism present in liver diseases $^{7}$ and to the physical inactivity. ${ }^{1}$

Several clinical situations may influence the albumin and immunological depletion such as the liver disease stage, hydroeletrolitic unbalance, renal failure, intestinal malabsorption, and immunosuppression. ${ }^{4,8}$ Therefore, visceral protein and TLC depletion have been correlated to the severity of the liver disease rather than to the malnutrition degree.

The analysis of nutritional studies in cirrhotic patients has been associated to some difficulties in a clinical perspective, to a disparity in the real prevalence of malnutrition in several studies that depends on the used parameters. ${ }^{9}$

Overall, by using standard anthropometry, the malnutrition has been reported in $33 \%$ to $43 \%$ of the liver transplant candidates. ${ }^{10,11}$ However, when using immunological function or visceral proteins to assess the nutritional status, the prevalence seems to be as high as $90 \%$ and $100 \%$, respectively. ${ }^{11}$

\section{CONCLUSION}

It was concluded that the PEM prevalence depends on the nutritional parameters and the studied population. A broader amount of measures should be used in order to allow more accurate studies.
Table 1: Nutritional status of subjects

\begin{tabular}{|c|c|c|c|}
\hline Anthropometric category & & Parameters & Results \\
\hline \multirow{6}{*}{$\mathrm{BMI}(\mathrm{Kg} / \mathrm{m} 2)$} & Malnutrition & $\leq 18,4 \mathrm{Kg} / \mathrm{m} 2$ & $5(15,1 \%)$ \\
\hline & Normal Weight & $18,5-24,9 \mathrm{Kg} / \mathrm{m}^{2}$ & $14(42,4 \%)$ \\
\hline & Overweight: & $25-29,9 \mathrm{Kg} / \mathrm{m}^{2}$ & $10(30,3 \%)$ \\
\hline & Obese class I & $20-34,9 \mathrm{Kg} / \mathrm{m}^{2}$ & $1(3 \%)$ \\
\hline & Obese class II & $35-39,9 \mathrm{Kg} / \mathrm{m}^{2}$ & $2(6,1 \%)$ \\
\hline & Obese class III & $\geq 40 \mathrm{Kg} / \mathrm{m}^{2}$ & $1(3 \%)$ \\
\hline \multirow{6}{*}{ \%DBW/IBW } & Severe malnutrition & $\leq 70 \%$ & 0 \\
\hline & Moderated malnutrition & $70,1-80 \%$ & $1(3 \%)$ \\
\hline & Light malnutrition & $80,1-90 \%$ & $2(6,1 \%)$ \\
\hline & Normal Weight & $90,1-110 \%$ & $12(36,4 \%)$ \\
\hline & Overweight: & $110,1-120$ & $2(6,1 \%)$ \\
\hline & Obesity & $>120 \%$ & $16(48,5 \%)$ \\
\hline \multirow{6}{*}{$\% \mathrm{TSF}$} & Severe malnutrition & $\leq 70 \%$ & $9(27,3 \%)$ \\
\hline & Moderated malnutrition & $70,1-80 \%$ & $3(9,1 \%)$ \\
\hline & Light malnutrition & $80,1-90 \%$ & $3(9,1 \%)$ \\
\hline & Normal Weight & $90,1-110 \%$ & $3(9,1 \%)$ \\
\hline & Overweight & $110,1-120$ & $14(42,4 \%)$ \\
\hline & Obesity & $>120 \%$ & $1(3 \%)$ \\
\hline \multirow{4}{*}{$\% \mathrm{MMA}$} & Severe malnutrition & $\leq 70 \%$ & $16(48,5 \%)$ \\
\hline & Moderated malnutrition & $70,1-80 \%$ & $1(3 \%)$ \\
\hline & Light malnutrition & $80,1-90 \%$ & $5(15,2 \%)$ \\
\hline & Normal & $>90 \%$ & $11(33,3 \%)$ \\
\hline \multirow[t]{4}{*}{$\% \mathrm{MMC}$} & Severe malnutrition & $\leq 70 \%$ & $2(6,1 \%)$ \\
\hline & Moderated malnutrition & $70,1-80 \%$ & $8(24,2 \%)$ \\
\hline & Light malnutrition & $80,1-90 \%$ & $10(30,3 \%)$ \\
\hline & Normal & $>90 \%$ & $13(39,4 \%)$ \\
\hline \multicolumn{4}{|l|}{ Laboratorial category } \\
\hline \multirow[t]{5}{*}{ Depletion of albumin } & Normal & $>3,5 \mathrm{~g} / \mathrm{dl}$ & $3(9,1 \%)$ \\
\hline & Light depletion & $3-3,5 \mathrm{~g} / \mathrm{dl}$ & $14(42,4 \%)$ \\
\hline & Moderate depletion & $2,4-2,9 \mathrm{~g} / \mathrm{dl}$ & $11(33,3 \%)$ \\
\hline & Severe depletion & $<2,4 \mathrm{~g} / \mathrm{dl}$ & $2(6,1 \%)$ \\
\hline & Without Information & & $3(9,1 \%)$ \\
\hline \multirow[t]{5}{*}{ TLC } & Normal & $>2000 / \mathrm{mm}^{3}$ & $13(39,4 \%)$ \\
\hline & Light depletion & $1200-2000 / \mathrm{mm}^{3}$ & $10(30,3 \%)$ \\
\hline & Moderate depletion & $800-1199 / \mathrm{mm}^{3}$ & $7(21,2)$ \\
\hline & Severe depletion & $<800 / \mathrm{mm}^{3}$ & $2(6,1 \%)$ \\
\hline & Without Information & & $1(3 \%)$ \\
\hline
\end{tabular}

$B M I=$ body mass index, \%DBW/IBW = percentage on adequacy of dry body weight / ideal body weight, \%TSF = adequacy of tricipital skin fold, \%MMC = adequacy of mid-arm muscular circumference $(\% M M C), \% M M A=$ uncorrected mid-arm muscular area, $T L C=$ total lymphocyte count. 


\section{RESUMO}

Introdução: A desnutrição é altamente prevalente em pacientes candidatos a transplante hepático. Sendo parâmetro preditivo de morbimortalidade, a adequada avaliação do estado nutricional nestes pacientes é útil no diagnóstico de importantes desvios e enseja a aplicação de medidas de correção capazes de melhorar o prognóstico. Objetivo: Avaliar o estado nutricional dos pacientes candidatos a transplante hepático em um Hospital Universitário. Métodos: Dos 44 pacientes listados, avaliaram-se 33, entre março de 2004 e janeiro de 2005. Os dados foram coletados através de análise retrospectiva de protocolos nutricionais e prontuários. Mensurou-se o peso atual, peso seco e peso ideal, índice de massa corpórea, percentagem adequação peso seco/peso ideal, prega cutânea tricipital, circunferência muscular do braço e área muscular do braço corrigida, depleção de albumina e contagem total de linfócitos. Resultados: Com a utilização do índice de massa corpórea e da percentagem peso seco/peso ideal, maiores freqüências de eutrofia e obesidade foram encontradas, respectivamente. A depleção protéica foi superior ao grau de depleção de tecido adiposo, principalmente pelo catabolismo próprio da doença e pela inatividade física. Conclusão: A prevalência de desnutrição varia conforme o tipo de avaliação nutricional utilizada e população estudada, sendo prudente utilizar o maior número possível de parâmetros, a fim de aumentar a confiabilidade dos resultados.

Descritores: Avaliação Nutricional, Transplante Hepático, Desnutrição, Contagem de Linfócitos.

\section{REFERÊNCIAS}

1. Vintro AD, Krasnoff JB, Painter P. Roles of nutrition and physical activity in musculoskeletal complications before and after liver transplantation. AACN Clinical Issues. 2002;13:333-47.

2. Aranda Michel J. Nutrition in hepatic failure and liver transplantation. Curr Gastroenterol. Rep. 2001;3:362-70.

3. Cabré E, Gassuli M. Nutritional and metabolic issues in cirrhosis and liver transplantation. 2000;3:345-54.

4. Parolin MB, Zaina FE, Lopes RW. Terapia nutricional no transplante hepático. Arq Gastroenterol. 2002;39:114-22.

5. Madden A, Wicks C. Monitoring nutritional status. In: Madden A, Wicks C, editors. A practical guide to nutrition in liver disease. London: British Dietetic Association. 1994;p.2-5.
6. Aiden Mc, Hade AM, Kennedy NP, Shine AM. Both under-nutrition and obesity increase morbidity following liver transplantation. The Irish Medical Journal. 2003;96

7. Vintro AQ. The continuity of nutrition care through liver transplantation. Nutrition in Clinical Care. 2001;4:70-86.

8. Ramaccioni V, Soriano HE, Arumugam R, Klish WJ. Nutritional aspects of chronic liver disease and liver transplantation in children. J Pediatr Gastroenterol Nutr. 2000;30:361-7.

9. Candela CG, Erdozain JC, Lobo RM, Blanco AC. Nutrición e hígado - transplante hepático. Rev Bras Nutr Clin. 2002;17(supl.1):64-71.

10. Muller MJ, Lautz HU, Plogmann B et al. Energy expenditure and substrate oxidation in patients with cirrhosis: the impact of cause, clinical staging and nutritional state. Hepatology. 1992;15:782-94.

11. Nompleggi DJ, Bonkovsky HL. Nutritional supplementation in chronic liver disease: an analytical review. Hepatology. 1994;19:518-33. 